\title{
Inside Noise: Intersemiotic Translation and Metatheatre in Radio Drama ${ }^{1}$
}

It is fascinating to observe different ways in which radio drama enthusiasts and researchers constantly have to reassert the need for their focusing on the art of radio drama. It is enough to browse through a selection of the most significant representatives in this research field to notice how they paraphrase one another in their justifications. In 1981 John Drakakis, began the introduction to his seminal work British Radio Drama by stating that radio plays are characterized by "sporadic" and "incomplete" history (Drakakis 1981: 1). Almost 20 years later, in 1999, another important radio drama researcher Tim Crook echoed Drakakis' observation when in the acknowledgements section of his Radio Drama: Theory and Practice he called radio plays "the most understated creative, dramatic and literary art [form]". Indeed, it seems that even one of the major contributions to the close analytical study of radio drama, that is Elissa S. Guralnick's Sight Unseen: Beckett, Pinter, Stoppard and Other Contemporary Dramatists on Radio from 1996 has not influenced the perception of radio drama as a subject worthy of scholarly analysis. She combines the inherent invisibility of radio plays with their low academic status:

The distinguishing feature of plays conceived for radio, that we do not see them, is true not only literally, but also metaphorically. Unlikely to be noticed in reviews or in scholarship, even less likely to be published [...] radio plays ghost away on the airwaves, leaving behind not a trace of their existence. (Guralnick 1996: ix)

And although radio drama seems not to be leaving scholarly interests - good examples of which being Immaterial Culture: Literature, Drama

1 This article was first published under the title "Inside Noise: A Case of Intersemiotic Translation and Metatheatre in Radio Drama" in Cultural Intertexts, Year 5, Vol. 8/2018: 32-44. 
and the American Radio Play, 1929-1954 by Harry Heuser or the special issue of "Tekstualia" (1/2013), just to give the most recent examples - it is compelling to begin one's own study of yet another aspect of radio drama by justifying its relevance for academic study, even if only by signalling that virtually every researcher faces the problem of introducing it by resorting to its academic negligence (or perhaps every researcher has the problem solved due to the unchanging validity of the previously made statements in that matter). Therefore, it seems safe to claim that this paper suggests another approach to the rich field of scattered radio drama analysis and aims to locate itself in the field of semiotic approach to radio plays, which is not altogether unfamiliar. It is enough to mention one of the most outstanding works in this respect, Andrew Crisell's Understanding Radio, whose chapter on radio signs and codes consistently follows the principles of semiotics, enriched by other broad insights, for example from music theory (cf. Crisell 1986: 45-56).

With the beginning of the so-called era of "web 2.0", which quite obviously includes the rapid proliferation of podcasts, streaming content and readily available software for all interested in sound and voice production, radio drama may be said to have entered a new phase, this time connected with its greater accessibility and faster dissemination. ${ }^{2}$ These numerous technological advances - which there is no room to discuss at this point - result in two major consequences for radio drama.

Firstly, the turn of the $20^{\text {th }}$ and $21^{\text {st }}$ centuries brought more awareness of and a further proliferation of independent radio drama producers. These include, for instance, The Wireless Theatre Company in the UK or Chatterbox Audio Theater in the US. Such initiatives are supplemented by theatre groups which perform live radio drama, thus providing insights into the technicalities involved in radio drama productions which are incorporated into the form and content of radio plays themselves. ${ }^{3}$

Secondly, and perhaps even more importantly, the internet has the most important influence on the accessibility of radio drama. The

${ }^{2}$ For an overview of earlier stages of radio drama development see the insightful chapter "The Six Ages of Radio Drama and the Internet Epoch" (Crook 1999: 21-29). An attempt to bridge the gap between the pre-Internet and "web 2.0" developments in radio drama is The Radio Drama Handbook: Audio Drama in Context and Practice (2011) by R. J. Hand and M. Traynor, where a historical overview of radio drama development until the year 2011 is combined with direct advice on how to become a self-made radio drama creator with the use of modern technology available via the internet. See also Hilmes 2001: 1-20.

${ }^{3}$ Interesting examples in this respect are provided especially by American theatre groups: e.g. Hope Leaves the Theater by Theatre of the New Ear (2005), SITI Company's Radio Macbeth (2007), or Noel Coward's Present Laughter (2012) by Gotham Radio Theatre. 
possibility to listen to radio online means relieving the listeners from the time constraints of broadcasts. Here, BBC Sounds - with virtually all radio content available after broadcast - stands out as a prominent example. As Lawrence Raw rightly observes, listeners are able to control their listening experience "rather than [be] at the scheduling and archiving whims of individual radio stations and/or their controllers" (Raw 2013: 37-38), a further consequence of it being a greater internationalization of radio drama content.

The fact that modern technology provides an opportunity for multiple broadcasts of one single radio play can undoubtedly facilitate academic, and if not academic then at least a closer study of radio drama. What is more, this reflects the long-awaited need to see radio drama as more than a one-off event. As one of the leading post-war radio drama researchers Donald McWhinnie succinctly noted in 1959:

I do believe that any artistic experience worth having can only be enriched by a second acquaintance, and the more profound the content the more closely you need to study it, as you come back again and again to a painting or a piece of music to discover new perspectives, new shades of meaning. (qtd. in Hand, Traynor 2011: 60)

The above quotation brings us to the methods of studying plays. These varied a lot from the very inception of radio dramatic forms. Although "by 1930 a basic grammar of radio production had been formulated", the vocabulary of radio drama was borrowed from such diverse disciplines as film, literature, theatre or psychology (Drakakis 1981: 7). This interdisciplinarity of theoretical approaches to radio drama seems to have been developing until the present times (to include for instance adaptation studies ${ }^{4}$ ). Its characteristic feature is the fact that no theories established at the very beginning of radio studies have been consigned to oblivion. They are constantly reformulated or retrieved from obscurity in order to yield new insights to the developing radio form of artistic expression. Good examples of such practices may be the incorporation of Lance Sieveking's theories by Tim Crook in his Radio Drama: Theory and Practice (1999: 70-89) or, in the field of Polish studies on radio drama, the return to phenomenological and aesthetic theories of Leopold Blaustein from the inter-war period (Łastowiecki 2013: 39-52).

${ }^{4}$ See, for example, Dwa teatry. Studia z zakresu teorii i interpretacji sztuki stuchowiskowej (Pleszkun-Olejniczakowa, Bachura, Pawlik 2001) and there articles entitled "Język adaptacji radiowej w słuchowisku Od siódmej rano" by Joanna Bachura (365-380) or "Pułapki adaptacji radiowej. Kilka uwag o dziele audialnym Ciotka Julia i skryba według powieści Mario Vargasa Llosy" by Aleksandra Pawlik (395-409). 
When analysing the nature of radio drama, Dermot Rattigan in his Theatre of Sound: Radio and the Dramatic Imagination (2002) provides a neat diagram of radio drama's constituent parts and it is quite obvious that the underlying theoretical assumptions are based here on semiotics (Rattigan 2002: 222). The two opposing poles of the diagram present the dramatic text and the performance text, which instantly brings to mind such semiotic discussions of drama/theatre relationships as the classic one by Anne Ubersfeld in her Reading Theatre (1999). The numerous elements located between both texts imply that the script of radio drama has to undergo a certain process of translation into signs of a different nature in order to become a fully realized radio production. ${ }^{5}$ This kind of translation, therefore, can safely be called intersemiotic, as it mediates between two different semiotic systems: that of the written text and of its sound realization. ${ }^{6}$ This application, albeit indirect in Rattigan's case, of semiotic terminology is nothing surprising and even taken for granted among radio drama researchers (see, for instance, Crisell, White, or Bachura in Poland). However, it is interesting that the concept of intersemiotic translation is mainly, if not exclusively, used to study how the meanings are produced by various elements of radio drama on its way from the script to the listener's ear (as Rattigan's diagram proves). What could further these analyses is attempting to find out how the concept of intersemiotic translation could be used for the discussion of the worlds created by radio drama, that is within the imaginary realms created by radio productions.

Taking the above as the starting point, in this paper I would like to show how intersemiotic translation works inside a radio play. I want to focus specifically on one recent BBC radio production entitled Noise (2012) by Alex Bulmer ${ }^{7}$ and on the basis of it present the way in which various semiotic systems (in spite of the apparent limitations of radio drama as a purely sound medium) interact on various levels. This, in turn, reveals intersemiotic translation within radio drama as conducive to emphasizing its dramatic form, which further results in uncovering radio drama's metatheatrical elements.

${ }^{5}$ Rattigan calls the two opposing processes "literary inception" and "aural realization" (2002: 222).

6 The term "intersemiotic translation" is used here after R. Jakobson, who in his essay "On Linguistic Aspects of Translation" defines intersemiotic translation as an interpretation of verbal signs into non-verbal ones. By extension, intersemiotic translation can be understood more broadly as an interpretation of one semiotic system by another.

7 First broadcast on 20 March 2012, BBC Radio 4. 
Noise tells the story of an orphan of Polish origin, a young woman called Kit, who is suffering from a memory loss. Her amnesia is the result of a serious case of hypothermia whose causes are unknown at the beginning of the story. After some time spent in a special clinic, where she takes part in sessions with the psychologist Helena, Kit goes back home and is taken care of by her partner Dan, a freelance music editor and an ex-lecturer. As the story develops, the listener learns that shortly before Kit's accident her relationship with Dan was on the verge of falling apart. Now Dan tries to take advantage of Kit's memory loss in order to replace her original memories with the ones he creates in his own studio by remixing the recordings from their past. He is almost successful when Kit's two encounters - first with Helena, and next with Dan's colleague Matt - spark off a chain of associations in her head that lead to her final realization that she has been cheated and that Dan is responsible for her suffering.

The play begins with a mixture of inexplicable voices, sounds and a piano tune. They together create the title noise which is going to be deciphered for the listeners in the course of the play. Out of the noise, the sound of an encephalograph comes to the fore, which signifies the space of the hospital in which we first meet Kit. The first words of the play are spoken by Dan. His exclamation "She blinked!"8 marks Kit's transition from the unconscious state in which only sounds dominate to the visual reality with language as its defining feature (the listeners would not know what happens to Kit if it were not for Dan's words). Thus, the transition may be said to take place between the aural and visual/verbal semiotic systems, although Kit's core memories still remain in the sound sphere. Additionally, the beginning of the play swiftly foregrounds Kit as the main character by giving the listeners access to her mind's 'noise' out of which they accompany her in entering the visual world.

The next step for Kit is to get accustomed to reality again after the shock of hypothermia, which means learning the basics of everyday life anew. Her first helper - to use Mukařovský's terminology - is Helena, who from the very beginning takes total control over Kit's convalescence by isolating Kit from Dan and arranging regular sessions with the girl. During these meetings Helena turns out to be a very matter-of-fact doctor who tries to awaken self-confidence in Kit and build in her mind a consistent picture of reality.

It is interesting to observe how much emphasis Helena puts on language. Even before the beginning of the therapy, Helena hears Kit

${ }^{8}$ All quotations from the play are from my own transcript. 
slowly uttering the sequence of letters "ABD", which she instantly corrects to "ABC" in accordance with the alphabetical system. It is only later revealed that Kit at that moment is naming the notes of the melody (so, in other words, sequence of sounds) she remembers. However, Helena's concentration on the linguistic aspect of reality is too strong to consider the sequence from a wider perspective. This linguistic focus is further proved by Helena's request that Kit should keep a journal in which she would record all events of a given day so that she could later reread them and gradually construct reliable reality around her.

On the one hand, the journal is supposed to facilitate the recovery of memory which may be frequently overburdened with the information coming in every minute. As Yury Lotman rightly observes, the "written text and the process of writing shift the burden of memory from an individual to an external symbolic system". At the same time, however, language in this case acts like a "condenser of memory" (qtd. in Andrews and Maksimova 2008: 264), which results in the fact that the written down observations quite obviously present the subjective perception which cannot ever be verified again by any objective means, as going back in time is impossible. Therefore, at the very beginning of her recovery Kit is subjected to the process of reality transformation, albeit for a good purpose.

Helena further underlines the importance of keeping a journal by claiming that "[w]e need history". For her, the process of one's conscious act of writing can at least give an impression of maintaining control over one's life, as she advises Kit: "Take control of the things you can control". In this way, she asks Kit to "translate [herself] through [...] history" (Kloepfer and Shaw 1981: 33) ${ }^{9}$, which also implies an intersemiotic translation of her memories based on sound into the linguistic order that seems to govern the visible reality.

In their discussion on intersemiotic transposition, based on examples taken from poems accompanied by visual elements, Claus Clüver and Burton Watson observe:

[T] he interpenetration of visual and verbal signs is such that the meaning constructed from the text as a whole will be quite different from the meanings derived from the signs alone; not infrequently, the signs of one system by themselves do not permit the production of any coherent meaning at all. (1989: 57)

${ }^{9}$ Although Kloepfer and Shaw use the quoted statement in reference to prose works and the characters' relation to historical change, it seems also perfectly applicable to the context of the discussed play. 
This is exactly what Kit seems to be afraid of when she finally returns home and begins her struggle for independent life. As if to 'double check' reality of her new space, she keeps repeating the words which refer to objects or actions she is performing at a given moment (for example, while pouring hot water into a cup and brewing tea). The naming process she undertakes can seem to be an illustration of gluing together Saussurean signifieds and signifiers. In a comic exchange with Dan, Kit even questions the nature of the object called "coffee table" as they never put coffee on it. Thus, she underlines the arbitrariness of names given to objects in a language which she is forced to hold on to in order to regain her former self.

Dan's involvement in Kit's convalescence employs a different means. The man attempts to help Kit in her recovery by asking her to listen to selected recordings from the past that they both shared. Dan's strategy is based on his intimate knowledge of Kit. She does not realize it yet, but he is fully aware of Kit's previous fascination with music and, by extension, the reality of sound. That is why he chooses to appeal to her emotions through recorded voices which he has intentionally edited in advance. What is more, in his conversations with Kit - which he also records - he purposefully steers each dialogue in the direction which would equip him with more material for further editing. For instance, shortly after they arrive from the hospital, Dan encourages Kit to repeat the word 'home' with reference to the space of his flat in order to use her voice later as part of the recording which is to prove her former attachment to the life they spent together.

Thus, the word 'home' becomes a metonymy of security and lost happiness for Kit. The significance of this metonymy - which apart from a metaphor is, in Bruno Osimo's words, a "fundamental [mechanism] of meaning construction" (Osimo 2008: 329) in artistic texts (which a radio play can be an example of) - is intentionally narrowed by Dan in order to limit the range of possible interpretations that Kit might come up with while listening to the recordings. What is more, Osimo proposes to see single words as well as texts as metaphorical "mugs":

One mug (special nuance of a word) is the one that interests us in the given chronotopic context, but the other ones are inseparable, and go around with it. When we stop at a table to deliver our tray (word), we put down our tray having in mind one particular mug (acceptation), but our receivers, sitting at the table, since we (inevitably) give them a lot of mugs with different drinks (acceptations), may decide that they prefer to interpret our word as composed of some other drink, and we, senders, don't always realize that. (Osimo 2008: 328-329) 
Kit is actually unable to see beyond a much broader scope of possible interpretations due to Dan's interference with the recordings. The fact that Dan wants to be the sole controller of sound reality for Kit is further highlighted by his admonition that she is never to enter his studio where he gives acoustic shape to his intrigue.

The "meaning-changing mechanism" (Osimo 2008: 330) that in Dan's case are the edited recordings may also influence the listeners' perception of the main protagonist's name. In this way, even the seemingly stable proper name becomes a fluid concept (cf. Osimo 2008: 330-331). Under Dan's control, Kit becomes a metaphorical "tool kit" which he makes use of to realize his plan of keeping his partner forever subordinate to him. The listeners are being reminded of the man's obsession with control every time Dan is alone working on his recordings - at these moments piano music, the same as the one in Kit's head in the opening of the play, is audible in the background.

Therefore, it seems justifiable to claim that two semiotic systems are in conflict inside Kit. Inspired by Helena, Kit strives to establish some contact with reality through the spoken and written language that are to remain in constant collaboration. On the other hand, her yet unrealized fascination with sound is abused by Dan, who provides her with fabricated facts. These two conflicting semiotic systems fight within Kit's mind and as the play progresses it transpires that the constant undermining of Helena's therapeutic measures by Dan's deception leaves Kit alone in her struggle for recovery.

The turning point for Kit comes with the unexpected visit of Dan's colleague Matt, who shortly before Kit's accident became her confidant. It is him to whom she confessed the problems she had with Dan's obsessive love for her. The meeting ends quite abruptly because Dan earlier falsely informs Kit that she was sexually abused by Matt. Having been isolated from all other people apart from Helena and Dan, Kit resorts to the only information she possesses and asks Matt to leave.

However, the visit is long enough to awaken Kit's suspicions. This takes place in an exchange which interweaves numerous strands of the semiotic systems presented in the play. As a music teacher who previously taught Kit to play the piano, Matt expresses his surprise at the fact that the piano in Dan and Kit's flat serves only as a support for flowers. For Kit, this object's function, which has been devised and imposed by Dan, is unquestionable. In Kit's linguistic system "piano" may only be a piece of decorative furniture, which is in agreement with the inexplicable nature of the above-mentioned coffee table. However, when Matt keeps insisting that the piano is actually Kit's property, brought to the flat of her own 
initiative, the two semiotic systems which Kit has so far tried to reconcile begin to be in conflict.

The linguistic system proposed by Helena seems to have failed, as the process of naming and assigning function is questioned by an outside observer in the person of Matt. Inevitably, Dan becomes the first suspect as it is him that prepared the flat before Kit's arrival from the hospital. In addition, Dan stands for the semiotic system of sound which provides Kit with her memories and is intended to help her construct an integrated personality. What is even more important, the object which triggers the conflict of semiotic systems may be also said to embody both of them. At first, piano for Kit is a linguistic construct with a function unconnected with any production of sound. After Matt's visit the piano reveals its potential for producing sounds which Kit can control - it was her who learnt to play it, the learnt piece was by Chopin and in fact it was his music that the listeners can hear at the beginning of the play and later in various moments of the story.

Thus, Kit undergoes a transformation. She starts from being an active interpreter and creator of the linguistic semiotic system and a mere recipient of the sound semiotic system. With the realization that she could and perhaps still can control sounds, Kit expands her area of independence and realizes that her freedom in interpreting reality can go beyond just one semiotic system.

The climax of the play results precisely from this realization. While preparing a special dinner to celebrate Kit's progress, the girl picks up on Dan's accidental remark about one of their trips and asks him to play one of the recordings again. It is important to notice that at this point it is she who for the first time makes a conscious decision about selection of sound input. After listening to the recording she quickly compares it with her written records in the journal and finds out a serious discrepancy between two versions of the same story. This pushes her to instinctively, and rightly, accuse Dan of deceiving her. Paradoxically, the inconsistency between two semiotic systems brings about her consistency of mind. This is how she becomes the organising agent in constructing her own independent perspective on the world.

The play ends with a mix of sounds, voices and noises that are almost identical with the opening sequence. Now, however, all elements are clear and understandable. Once more the listeners enter Kit's mind to find out that perhaps the form of her memories has not changed, but its content is finally decipherable. The last exchange between the characters belongs to Dan and Kit. After the man observes that the weather outside is so cold that it is hard to imagine anyone being able to endure such 
low temperatures, Kit answers briefly: "I can". Thus, she makes a double reference which points both to her regained physical endurance as well as mental abilities which she can now learn to control even more fully.

As it can be observed, intersemiotic translation in Noise works on numerous levels. With regard to therapeutic methods applied to Kit, Helena attempts to translate her sensations, feelings and observations into the semiotic system of language. Dan not only translates Kit's unconscious memories into sound, but first of all by fabricating them supplies the versions which conform to his devious plan. In each case, intersemiotic translation has Kit as its final recipient. Kit does not translate anything to either Helena, Matt or Dan until between the semiotic systems she notices interrelationships based on contradictions.

It is interesting to note that during the scene when Kit compares the two versions of her memories - one in sound and the other in its written form - it is the latter that turns out to find its additional confirmation in Matt's words during his visit. Therefore, in terms of the hierarchy of semiotic systems, the suggestion might be that it is the written record, which might be called a translation of a conceptual structure into its corresponding linguistic form (cf. Osimo 2002: 618-619), that is supposed to be credited with more reliability. At this point one is reminded of the above-mentioned diagram by Dermot Rattigan, in which the written text remains at the source of the aural realization of a radio play. Therefore, the hierarchy suggested inside the play Noise is also applicable to the process of creating radio drama, which always possesses the written text as its underlying and indispensable element. Such a connection provokes a discussion on metatheatrical elements as they are presented in the analyzed play.

In the words of Lionel Abel, metatheatrical plays

have a common character: all of them are theatre pieces about life seen as already theatricalized. By this I mean that the persons appearing on the stage in these plays are there not simply because they were caught by the playwright in dramatic postures as a camera might catch them, but because they themselves knew they were dramatic before the playwright took note of them. What dramatized them originally? Myth, legend, past literature, they themselves. They represent to the playwright the effect of dramatic imagination before he has begun to exercise his own; on the other hand, unlike figures in tragedy, they are aware of their own theatricality. Now, from a certain point of view, only that life which has acknowledged its inherent theatricality can be made interesting on the stage. From the same modern view, events, when interesting, will have the quality of having been thought, rather than of having simply occurred. (Abel 2003: 135) 
These remarks are only partly applicable to Noise. This is because, on the one hand, the listeners throughout the play are encouraged to accept that they are participating in the events that have "simply occurred". Kit has to struggle with her memory loss and at no time does she signal that as a person "appearing on the [radio] stage" she knows she is "dramatic before the playwright took note of [her]".

On the other hand, a closer look at Noise reveals that this radio drama is in fact about various aspects of creation, thus implying that "it was [the playwright's] imagination which controlled the event from beginning to end." Of course, the author does not enter the play in person, but he equips all his characters with the power of creation: Dan in his recordings creates memories for Kit; Helena creates a way of approaching reality in order to help Kit regain her former self; finally, Kit struggles to create her own world out of the contradictory elements she is supplied with.

Among metatheatrical elements enumerated by Patrice Pavis - which include for instance a play within a play, addressing the audience or placing theatre as the subject of dialogue (Pavis 2002: 287-289) - he also suggests that metatheatre is present everywhere the depicted reality resembles theatre. This is especially true of Noise, in which Dan is involved in the process of editing the recordings, which is precisely what takes place during the post-production of radio dramas. Therefore, the listeners experience post-production on a double level. They are faced with the effects of post production of the play called Noise (produced for the BBC by Polly Thomas) as a play about a man trying to post-produce a young woman's memories. In this way, everything that takes place once Kit moves to stay in Dan's flat resembles a carefully planned performance based primarily on verbal and sound elements, which radio drama actually is in its essence.

What is more, the fact that the play begins with the noise inside Kit's head gains here additional significance. By placing emphasis on the need for the disentanglement of the various sounds in Kit's memory the listeners are persuaded to think of the radio play Noise as a collection of Kit's memories which are remixed by Dan, transcribed with Helena's help and targeted at Kit as the ultimate listener within the world of radio drama.

When one steps beyond this world and becomes conscious of his role as a listener, the fact to be considered is the moment when Kit finds her independent way to regaining memory through combining contradictory verbal and sound inputs she has received. Transferred to the sphere of radio drama reception, Kit's decisions suggest that it is possible that the unity of word and sound in radio plays provides the best analytical 
material for their audiences. Just like Kit's understanding arises out of the discovery of interrelationships and contradictions which she is left alone to decipher, the task of the listener - also alone in his experience of listening to radio drama - also seems to hinge on being careful of gaps that have to be filled in. These do not refer to the playwright's or producer's slips, but to the organising power of the listeners' imagination whose aim is to discover the "translation system" peculiar to a given radio play and then learn its "system of teaching it" (Kloepfer and Shaw 1981: 34) to the listener.

\section{References}

Abel, Lionel (2003). Tragedy and Metatheatre. Ed. Martin Puchner. New York: Holmes and Meier.

Andrews, Edna, and Elena Maksimova (2008). "Semiospheric Transitions: A Key to Modelling Translation". Sign Systems Studies 36 (2): 259-269.

Bachura, Joanna (2012). Odsłony wyobraźni. Współczesne słuchowisko radiowe. Toruń: Wydawnictwo Adam Marszałek.

320 Bulmer, Alex (2012). Noise. BBC Radio 4. 20 March. Broadcast.

Clüver, Claus, and Burton Watson (1989). "On Intersemiotic Transposition". Poetics Today 10 (1): 55-90.

Crisell, Andrew (1986). Understanding Radio. London: Methuen.

Crook, Tim (1999). Radio Drama: Theory and Practice. London: Routledge.

Drakakis, John (ed.) (1981). British Radio Drama. Cambridge: Cambridge University Press.

Guralnick, Elissa S. (1996). Sight Unseen: Beckett, Pinter, Stoppard and Other Contemporary Dramatists on Radio. Athens: Ohio University Press.

Hand, Richard J., Mary Traynor (2011). The Radio Drama Handbook: Audio Drama in Context and Practice (Audio Drama in Practice and Context). New York and London: Continuum Books.

Heuser, Harry (2013). Immaterial Culture: Literature, Drama and the American Radio Play, 1929-1954. Bern: Peter Lang AG.

Hilmes, Michelle (2001). "Rethinking Radio". In: Radio Reader: Essays in the Cultural History of Radio. Eds. Michele Hilmes, and Jason Loviglio. (1-20). London: Routledge.

Jakobson, Roman (1959). “On Linguistic Aspects of Translation". In: On Translation. Ed. Reuben Arthur Brower. (260-66). Cambridge: Harvard University Press.

Kloepfer, Rolf, and Ph. Shaw (1981). "Intra- and Intercultural Translation". Poetics Today 2 (4): 29-37.

Łastowiecki, Janusz (2013). “Wielka wspólnota osobnych”. Tekstualia 32 (1): 39-52. 
Osimo, Bruno (2002). “On Psychological Aspects of Translation”. Sign Systems Studies 30 (2): 607-27.

Osimo, Bruno (2008). "Jakobson: Translation as Imputed Similarity". Sign Systems Studies 36 (2): 316-39.

Pavis, Patrice (2002). Stownik terminów teatralnych. Trans. Sławomir Świontek. Wrocław: Zakład Narodowy im. Ossolińskich.

Pleszkun-Olejniczakowa, Elżbieta, Joanna Bachura, and Aleksandra Pawlik (2011). Dwa teatry. Studia z zakresu teorii i interpretacji sztuki stuchowiskowej. Toruń: Wydawnictwo Adam Marszałek.

Rattigan, Dermot (2002). Theatre of Sound: Radio and the Dramatic Imagination. Dublin: Carysfort Press.

Raw, Lawrence (2013). “Jane Austen on Old-Time Radio: Creating Imaginative Worlds". In: Global Jane Austen. Pleasure, Passion, and Possessiveness in the Jane Austen Community. Eds. Lawrence Raw, Robert Dryden. (37-50). New York: Palgrave Macmillan.

Ubersfeld, Anne (1999). Reading Theatre. Eds. Jean-Patrick Debbeche, and Paul J. Perron. Trans. Frank Collins. Toronto: University of Toronto Press.

White, John J. (2005). "Coconut Shells and Creaking Doors: A Semiotic Approach to the Avant-Garde Radio Play's Sound-Effects". Outside-in, Inside-out: Iconicity in Language and Literature 4. Eds. Costantino Maeder, Olga Fischer, William J. Herlofsky. (151-169). Amsterdam: John Benjamins Publishing. 